medRxiv preprint doi: https://doi.org/10.1101/2022.01.20.22269599; this version posted January 23,2022 . The copyright holder for this preprint (which was not certified by peer review) is the author/funder, who has granted medRxiv a license to display the preprint in perpetuity.

It is made available under a CC-BY-NC-ND 4.0 International license .

\title{
Predictive performance and clinical application of COV50, a urinary proteomic biomarker in early COVID-19 infection: a cohort study
}

Short title: COV50 as guide to earlier COVID-19 treatment

Jan A. Staessen, ${ }^{*}$ Ralph Wendt, ${ }^{*}$ Yu-Ling Yu, Sven Kalbitz, Lutgarde Thijs, Justyna Siwy, Julia Raad, Jochen Metzger, Barbara Neuhaus, Armin Papkalla, Heiko von der Leyen, Alexandre Mebazaa, Emmanuel Dudoignon, Goce Spasovski, Mimoza Milenkova, Aleksandra Canevska-Taneska, Mina Psichogiou, Marek W. Rajzer, Lukasz Fulawka, Magdalena Dzitkowska-Zabielska, Guenter Weiss, Torsten Feldt, Miriam Stegemann, Johan Normark, Alexander Zoufaly, Stefan Schmiedel, Michael Seilmaier, Benedikt Rumpf, Mirosław Banasik, Magdalena Krajewska, Lorenzo Catanese, Harald Rupprecht, Beata Czerwienska, Björn Peters, Åsa Nilsson, Katja Rothfuss, Christoph Lübbert, Harald Mischak, $\uparrow$ Joachim Beige, $\uparrow$ the CRIT-Cov-U investigators $\ddagger$

Word counts: manuscript 7053, article text, 2992, summary 346 Number: 4 tables, 1 figure; references 32

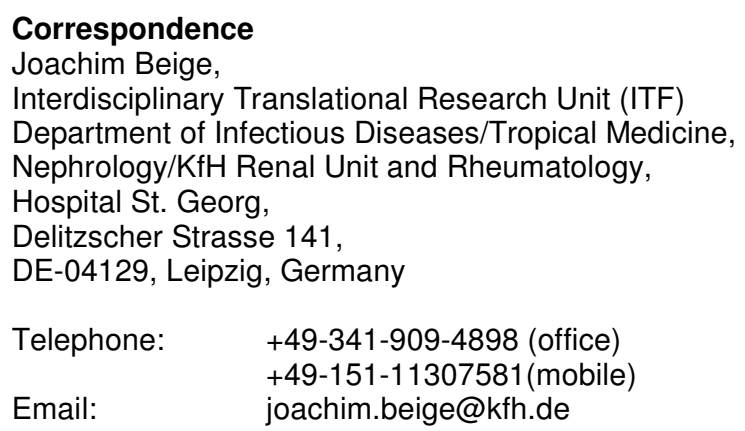


medRxiv preprint doi: https://doi.org/10.1101/2022.01.20.22269599; this version posted January 23,2022 . The copyright holder for this preprint (which was not certified by peer review) is the author/funder, who has granted medRxiv a license to display the preprint in

It is made available under a CC-BY-NC-ND 4.0 International license.

COV50 as guide to earlier COVID-19 treatment -2-

Affiliations

Non-Profit Research Institute Alliance for the Promotion of Preventive Medicine, Mechelen (Prof JA Staessen MD), Belgium, Biomedical Sciences Group, Faculty of Medicine, University of Leuven, Leuven, Belgium (Prof JA Staessen MD), Department of Infectious Diseases/Tropical Medicine, Nephrology/KfH Renal Unit and Rheumatology, St. Georg Hospital Leipzig, Germany (R Wendt MD, S Kalbitz MD, Prof C Lübbert MD, Prof J Beige MD), Research Unit Environment and Health, Department of Public Health (Y-L Yu MD) and Research Unit Hypertension and Cardiovascular Epidemiology, Department of Cardiovascular Diseases, University of Leuven, Leuven, Belgium (L Thijs MSc), Mosaiques-Diagnostics GmbH, Hannover, Germany (J Siwy PhD, J Raad PhD, J Metzger PhD, Prof H Mischak PhD), Center for Clinical Trials - CTS, Medizinische Hochschule, Hannover, Germany (B Neuhaus PhD, A Papkalla PhD, Prof H von der Leyen, MD), Department of Anaesthesiology and Intensive Care, Hospital Saint LouisLariboisière, Paris, France (Prof A Mebazaa MD, E Dudoignon MD), Cyril and Methodius University, Skopje, Republic of North Macedonia (Prof G Spasovski MD, M Milenkova MD, A Canevska-Taneska MD), First Department of Internal Medicine, Laiko General Hospital, National and Kapodistrian University of Athens Medical School, Athens, Greece (M Psichogiou MD), First Department of Cardiology, Interventional Electrocardiology and Arterial Hypertension, Jagiellonian University Medical College, Kraków, Poland (Prof MW Rajzer MD), Molecular Pathology Centre Cellgen, Wroclaw, Poland (L Fulawka MD), Faculty of Physical Education, Gdansk University of Physical Education and Sport (M Dzitkowska-Zabielska MD), Center of Translational Medicine, Medical University of Gdańsk, Poland (M Dzitkowska-Zabielska MD), Department of Infectious Diseases and Respiratory Medicine, Charité - Universitätsmedizin Berlin, corporate member of Freie Universität Berlin and Humboldt-Universität zu Berlin, Germany (M Stegemann, MD), Department of Internal Medicine II, Medical University Innsbruck, Innsbruck, Austria (G Weiss MD), Department of Gastroenterology, Hepatology and Infectious Diseases, Medical Faculty of Heinrich Heine University, Düsseldorf, Germany (T Feldt MD), 
medRxiv preprint doi: https://doi.org/10.1101/2022.01.20.22269599; this version posted January 23,2022 . The copyright holder for this preprint (which was not certified by peer review) is the author/funder, who has granted medRxiv a license to display the preprint in It is made available under a CC-BY-NC-ND 4.0 International license

COV50 as guide to earlier COVID-19 treatment -3-

Wallenberg Centre for Molecular Medicine, Department of Clinical Microbiology, Umeå University, Umeå, Sweden (J Normark MD), Department of Medicine IV, Clinic Favoriten and Faculty of Medicine, Sigmund Freud University, Vienna, Austria (A Zoufaly MD), Nephrology and Dialysis, Internal Medicine III, Medical University of Vienna, Vienna, Austria (B Rumpf MD), Department of Nephrology and Transplantation Medicine, Wroclaw Medical University, Wroclaw, Poland (M Banasik MD, Prof M Krajewska MD), University of Silesia, Katowice, Poland (B Czerwienska MD), Department of Nephrology, Skaraborg Hospital, Skövde and Department of Molecular and Clinical Medicine, Institute of Medicine, The Sahlgrenska Academy at University of Gothenburg, Sweden (B Peters MD), Research and Development Centre, Skaraborg Hospital, Skövde, Sweden (B Peters MD, Å Nilsson MSc), Department of Nephrology, Angiology and Rheumatology, Hospital Bayreuth (L Catanese MD), Margarete-Fischer-Bosch Institute for Clinical Pharmacology and Division of Infectious Diseases, Robert Bosch Hospital, Stuttgart, Germany (K Rothfuss MD), Medical Department I and Bernhard-Nocht-Clinic for Tropical Medicine, University Medical Center Hamburg Eppendorf, Hamburg, Germany (S Schmiedel, MD), Department of Haematology, Oncology, Immunology, Palliative Care, Infectious Disease and Tropical Medicine, München Klinik Schwabing, München, Germany (M Seilmaier, MD), Division of Infectious Diseases and Tropical Medicine, Leipzig University Medical Center, Leipzig, Germany (Prof C Lübbert MD), Institute of Cardiovascular and Medical Sciences, Glasgow, United Kingdom (Prof H Mischak PhD), Martin-Luther-University HalleWittenberg, Halle an der Saale, Germany (Prof J Beige MD).

\footnotetext{
* Joint first authors who contributed equally

† Joint senior authors who contributed equally

‡ CRIT-Cov-U investigators are listed in the appendix 1 (pp 6-7).
} 
medRxiv preprint doi: https://doi.org/10.1101/2022.01.20.22269599; this version posted January 23, 2022. The copyright holder for this preprint (which was not certified by peer review) is the author/funder, who has granted medRxiv a license to display the preprint in It is made available under a CC-BY-NC-ND 4.0 International license.

COV50 as guide to earlier COVID-19 treatment -4-

Correspondence to Prof Joachim Beige, Martin-Luther-University Halle/Wittenberg, Delitzscher Strasse 141, DE-04129, Leipzig, Germany.

E-mail: joachim.beige@kfh.de 
medRxiv preprint doi: https://doi.org/10.1101/2022.01.20.22269599; this version posted January 23,2022 . The copyright holder for this preprint (which was not certified by peer review) is the author/funder, who has granted medRxiv a license to display the preprint in It is made available under a CC-BY-NC-ND 4.0 International license .

COV50 as guide to earlier COVID-19 treatment -5-

\section{Summary}

Background The SARS-CoV-2 pandemic remains a worldwide challenge. The CRIT-Cov-U pilot study generated a urinary proteomic biomarker consisting of 50 peptides (COV50), which predicted death and disease progression. Following the interim analysis demanded by the German government, the full dataset was analysed to consolidate findings and propose clinical applications.

Methods In eight European countries, 1012 adults with PCR-confirmed COVID-19 were followed up for death and progression along the 8-point WHO scale. Capillary electrophoresis coupled with mass spectrometry was used for urinary proteomic profiling. Statistical methods included logistic regression, receiver operating curve analysis with comparison of the area under curve (AUC) between nested models. Hospitalisation costs were derived from the care facility corresponding with the Markov chain probability of reaching $\mathrm{WHO}$ scores ranging from 3 to 8 and flat-rate hospitalistion costs standardised across countries.

Findings The entry WHO scores were 1-3, $4-5$ and 6 in $445(44 \cdot 0 \%), 529(52 \cdot 3 \%)$, and 38 (3.8\%) patients, of whom 119 died and 271 progressed. The standardised odds ratios associated with COV50 for death were $2 \cdot 44(95 \% \mathrm{Cl}, 2 \cdot 05-2 \cdot 92)$ unadjusted and 1.67 (1.342.07) if adjusted for sex, age, body mass index, comorbidities and baseline WHO score, and $1 \cdot 79(1 \cdot 60-2 \cdot 01)$ and $1.63(1 \cdot 40-1 \cdot 90)$, respectively, for disease progression $(p<0.0001$ for all). The predictive accuracy of optimised COV50 thresholds were $74 \cdot 4 \%$ (95\% Cl, 71·677·1) for mortality (threshold $0 \cdot 47)$ and $67 \cdot 4 \%(64 \cdot 1-70 \cdot 3)$ for disease progression (threshold 0.04). On top of covariables and the baseline WHO score, these thresholds improved AUCs from 0.835 to $0.853(p=0.0331)$ and from 0.697 to $0.730(p=0.0008)$ for death and 
medRxiv preprint doi: https://doi.org/10.1101/2022.01.20.22269599; this version posted January $23,2022$. The copyright holder for this preprint (which was not certified by peer review) is the author/funder, who has granted medRxiv a license to display the preprint in It is made available under a CC-BY-NC-ND 4.0 International license.

COV50 as guide to earlier COVID-19 treatment -6-

progression, respectively. Of 196 ambulatory patients, 194 (99.0\%) did not reach the 0.04 threshold. Earlier intervention guided by high-risk COV50 levels should reduce hospital days with cost reductions expressed per 1000 patient-days ranging from M€ 1.208 (95\% percentile interval, $1 \cdot 035-1 \cdot 406)$ at low risk (COV50 <0.04) to M€ 4.503 $(4 \cdot 107-4 \cdot 864)$ at high risk (COV50 $\geq 0.04$ and age $\geq 65$ years).

Interpretation The urinary proteomic COV50 marker is accurate in predicting adverse COVID-19 outcomes. Even in mild-to-moderate PCR-confirmed infections (WHO scores 15), the 0.04 threshold justifies earlier drug treatment, thereby reducing hospitalisation days and costs.

Funding German Federal Ministry of Health acting upon a decree from the German Federal Parliament.

Copyright ( The Author(s). Published by Elsevier Ltd. This is an Open Access article under the CC BY-NC-ND 4.0 License.

Key words COVID-19, disease severity, risk score, SARS-CoV-2, urinary proteomics, World Health Organization scale 
medRxiv preprint doi: https://doi.org/10.1101/2022.01.20.22269599; this version posted January 23,2022 . The copyright holder for this preprint (which was not certified by peer review) is the author/funder, who has granted medRxiv a license to display the preprint in It is made available under a CC-BY-NC-ND 4.0 International license.

COV50 as guide to earlier COVID-19 treatment -7-

\section{Introduction}

The SARS-CoV-2 pandemic remains a challenge for health care worldwide. Globally, during the week of $15-21$ November 2021 , nearly $3 \cdot 6$ million new cases and over 51,000 deaths were reported, reflecting $6 \%$ increases in both metrics compared to the preceding week. 1 While the pandemic is stretching health care resources over what is sustainable in the long run, the world is now bracing for the Omicron variant with higher transmissibility and potentially more resistance against the immunological response to vaccines or previous infection.2,3 Until now COVID-19 patients were stratified for risk based on age, obesity, comorbidities and disease-severity scales.

An extensive literature search (appendix 2) did not reveal any predictive biomarker allowing to select high-risk COVID-19 patients for early treatment. Urinary proteomic profiling (UPP) generates classifiers representative for pathogenic molecular mechanisms, which in case of SARS-CoV-2 infection are generally independent of mutating virus strains and which may inform treatment, in particular with pharmacological agents not specifically directed against the variable S-protein domains of evolving SARS-CoV2 strains. Following a insistent request from the German government, an interim analysis of the Prospective Validation of a Proteomic Urine Test for Early and Accurate Prognosis of the Critical Complications in Patients with SARS-CoV-2 Infection Study (CRIT-Cov-U) described the discovery, replication and internal and external validation of COV50. This novel UPP biomarker consists of 50 deregulated urinary peptides (appendix $1 p 8$ ) and predicts death and progression across the COVID-19 WHO stages over beyond risk factors and comorbidities. 4 The objectives of the current study were to consolidate the interim findings in the full study sample and to propose potential applications of the COV50 marker in clinical practice and trial design. 
medRxiv preprint doi: https://doi.org/10.1101/2022.01.20.22269599; this version posted January 23,2022 . The copyright holder for this preprint (which was not certified by peer review) is the author/funder, who has granted medRxiv a license to display the preprint in It is made available under a CC-BY-NC-ND 4.0 International license

COV50 as guide to earlier COVID-19 treatment -8-

\section{Methods}

CRIT-Cov-U project complies with the Helsinki declaration. The Ethics Committee of the German-Saxonian Board of Physicians, Dresden, Germany (number, EK-BR-88/20.1) and the Institutional Review Boards of the recruiting sites provided ethical clearance. The protocol is deposited at the German Register for Clinical Studies (www.drks.de; number DRKS00022495), which is linked to the WHO International Clinical Trial Registry Platform (www.who.int/clinical-trials-registry-platform).

CRIT-Cov-U was a prospective multicentre cohort study. 4 Eligible patients were nonanuric adults ( $\geq 18$ years), capable to give written informed consent, with PCR-confirmed SARS-CoV-2 infection diagnosed in ambulatory care or on the first hospitalisation day. All patients meeting the eligibility criteria were enrolled without any exclusion in two phases: 228 patients were recruited from 25 March 2020 until 18 November 2020 and were included in the interim report; 4 recruitment of 784 patients continued from 30 April 2020 until 14 April 2021, so that the full study cohort comprised 1012 individuals. Five centres participated in the initial enrolment of patients and an additional 12 in the continued recruitment. Two sites were located in Austria (65 patients enrolled), one in France (49), seven in Germany (458), one in Greece (30), one in North Macedonia (137), four in Poland (149), one in Spain (23), and two in Sweden (101).

All patients were followed up until recovery, hospital discharge or death. On days $0-3,4-7$ and 10-21 after diagnosis surviving patients were staged according to the 8-point WHO Clinical Progression Scale.5 Electronic case report forms (MARVIN EDC, XClinical GmbH, Munich, Germany) were used for data compilation. For UPP, 8 ml-urine samples were collected in borated test tubes (ExactoBac-U®, Sarstedt, Nümbrecht, Germany) and kept at $-20{ }^{\circ} \mathrm{C}$ until assayed. The methods for capillary electrophoresis coupled with mass 
medRxiv preprint doi: https://doi.org/10.1101/2022.01.20.22269599; this version posted January 23,2022 . The copyright holder for this preprint (which was not certified by peer review) is the author/funder, who has granted medRxiv a license to display the preprint in It is made available under a CC-BY-NC-ND 4.0 International license .

COV50 as guide to earlier COVID-19 treatment -9-

spectrometry, peptide sequencing, and for evaluation, calibration and quality control of the mass spectrometric data are described in detail in appendix 1 (p 2-5).

The initial sample size calculations informed by a proof-of-concept study6 required 212 patients with critical COVID-19 (WHO stage $\geq 6$ ) to be contrasted with 271 patients with mild symptoms (WHO stage $<4$ ) to identify and validate a UPP biomarker having $75 \%$ sensitivity and $80 \%$ specificity. Given the $33 \%$ progression rate from mild to severe disease in the pilot study 6 and accounting for $15 \%$ of missing data, the sample size for the full study was set at 645 patients. Based on the interim study, 4 in which the mortality rate was $10 \cdot 1 \%(23 / 228)$, the sample size for the full study was revised to 1000 patients.

For database management and statistical analysis, SAS software version 9.4 was used. Significance was a 2-tailed significance of 0.05 or less. Means and proportions were compared using the large-sample $\mathrm{z}$ test or ANOVA and Fisher's exact test, respectively. The predefined endpoints were mortality and progression across the 8-point WHO scale of disease severity. The $95 \%$ confidence intervals of rates were computed as $R \pm 1.96 \times$ $\sqrt{ }(\mathrm{R} / \mathrm{T})$, where $\mathrm{R}$ and $\mathrm{T}$ are the rate and the denominator used to calculate the rate. The risk of incident endpoints was related to the baseline COV50 level by logistic regression, unadjusted or adjusted for sex, age, the entry WHO scale and comorbidities including hypertension, heart failure, diabetes, and cancer. The differences in the COV50 odds ratios between initial and continued recruitment were tested by introduction of the interaction between study phase and baseline COV50 in the logistic models. Performance of COV50 in risk stratification was assessed by the area (AUC) under the receiver operating curve $(R O C)$ and the Delong approach to compare the AUCs between nested models. The COV50 thresholds optimised by the Youden index were 0.47 for mortality and 0.04 for worsening WHO score. 4 
medRxiv preprint doi: https://doi.org/10.1101/2022.01.20.22269599; this version posted January 23,2022 . The copyright holder for this preprint (which was not certified by peer review) is the author/funder, who has granted medRxiv a license to display the preprint in It is made available under a CC-BY-NC-ND 4.0 International license

COV50 as guide to earlier COVID-19 treatment $-\mathbf{1 0}$

A Markov chain analysis was conducted using SAS IML and bootstrapped 1000 times to generate the transition probabilities from the entry to follow-up WHO scores (appendix $1 \mathrm{p}$ 17). ${ }^{7}$ The transition probabilities were computed for various risk strata defined by the entry COV50 level and age ( $<65$ vs $\geq 65$ years). The transition probabilities allowed extrapolating the number of patients reaching follow-up WHO scores of $3-4,5$ and $6-8$, and therefore requiring regular, intermediate or intensive care. Given the simulated number of patients, hospitalisation costs were computed based on the median number of hospital days per care facility, as observed in the CRIT-Cov-U cohort, and a flat care-facility specific costing rate, which was harmonised across clinical sites based on each country's 2020 gross domestic product 8 with the diagnosis-related daily costs applicable in Germany as reference: $€ 540$, $€ 1590$, and $€ 1770$ for regular, intermediate and intensive care, respectively. Hospitalisation costs were expressed in million Euro $(\mathrm{M} €)$ for 1000 patients in each risk stratum.

\section{Role of the funding source}

The funder of the study had no role in the study design, data collection, data analysis, data interpretation, or the writing of the report. All authors had full access to all of the data in the study and had the final responsibility for the decision to submit the manuscript.

\section{Results}

The 1012 participants making up the full dataset were on average $62 \cdot 3$ years old, included $447(44 \cdot 2 \%)$ women, $557(55 \cdot 0 \%)$ patients with hypertension, $154(15 \cdot 2 \%)$ with heart failure, $257(25 \cdot 4 \%)$ with diabetes, and $106(10 \cdot 5 \%)$ patients with cancer (appendix 1 p 18). The WHO score at enrolment (table 1) was 1-3 in 445 (44.0\%) patients, 4-5 in 529 (52.3\%), and

6 in $38(3.8 \%)$. The median (interquartile range) COV50 level at baseline was $0.23(-1.27$ to 0.80; appendix 1 p 19). Compared with the initially enrolled patients, those recruited later 
medRxiv preprint doi: https://doi.org/10.1101/2022.01.20.22269599; this version posted January 23,2022 . The copyright holder for this preprint (which was not certified by peer review) is the author/funder, who has granted medRxiv a license to display the preprint in It is made available under a CC-BY-NC-ND 4.0 International license .

COV50 as guide to earlier COVID-19 treatment -11-

scored lower on the WHO scale (table $1 ; p<0.0001$ ), included more patients with a history of cancer ( 5.7 vs $11.9 \% ; p=0 \cdot 0117)$, but fewer participants on inhibitors of the reninangiotensin system (53.5\% vs 38.9\%; $p<0.0001)$. Otherwise, patients recruited initially and later had similar characteristics (table 1), in particular a comparable entry level of COV50 $(-0.19$ vs $-0.24 ; p=0.5918)$. In the whole study population (appendix $1 \mathrm{p} 11)$, the proportion of women and the mean values of diastolic blood pressure decreased across increasing fourths of the COV50 distribution, whereas age, heart rate and the rates of hypertension, heart failure, diabetes mellitus and cancer increased.

No patient was lossed to follow-up. Median (5th-95th percentile interval) follow-up was 10 days (1-34) for mortality (119 deaths) and 10 days (2-26) for worsening WHO score (271 cases). The baseline COV50 distribution shifted upward $(p<0.0001)$, when plotted against the worst WHO score attained during follow-up (appendix 1 p 20). In the whole study population (table 2), the relative risk of death expressed per 1-SD increment in COV50 at entry was 2.44 (95\% confidence interval, $2 \cdot 05-2 \cdot 92 ; p<0 \cdot 0001)$ unadjusted and 1.67 (1.342.07) when fully adjusted for sex, age, body mass index, the presence of comorbidities, and the baseline WHO score; for progression in the WHO score (table 3), the corresponding odds ratios were $1.79(1.60-2 \cdot 01)$ unadjusted and $1.63(1 \cdot 10-1 \cdot 90)$ fully adjusted. In analyses dichotomised by study phase, the risk associated with COV50 was similar for both endpoints, irrespective of adjustment (table 2). The unadjusted odds ratios for initial compared with continued recruitment were $2.45(1.69-3.54)$ vs $2.47(2.02-3.03)$ for mortality $(\mathrm{p}=0.9605)$ and $1.95(1.52-2.51)$ vs $1.77(1.56-1.73)$ for worsening WHO score $(p=0.5150)$. The corresponding fully adjusted estimates (table 2) were $2.27(1 \cdot 34-3 \cdot 83)$ vs 1.55 (1.211.98) for mortality $(\mathrm{p}=0.9380)$ and $1.95(1.52-2.51)$ vs $1.77(1.56-1.73)$ for worsening WHO score $(p=0 \cdot 1645)$. 
medRxiv preprint doi: https://doi.org/10.1101/2022.01.20.22269599; this version posted January 23,2022 . The copyright holder for this preprint (which was not certified by peer review) is the author/funder, who has granted medRxiv a license to display the preprint in It is made available under a CC-BY-NC-ND 4.0 International license .

COV50 as guide to earlier COVID-19 treatment -12-

In the whole study population, the AUC of the continuously distributed COV50 urinary marker was $0.81(95 \%$ confidence interval, $0 \cdot 77-0 \cdot 85)$ for mortality and $0.72(0 \cdot 62-0 \cdot 75)$ for worsening WHO score (table 3). The death rate among participants with a COV50 level less vs equal to or higher than the optimised threshold $(0 \cdot 47)$ was $30 / 694$ vs $89 / 318(4 \cdot 32 \%[95 \%$ confidence interval, $4 \cdot 17-4 \cdot 48]$ vs $28 \cdot 0 \%[27 \cdot 4-28 \cdot 6] ; p<0 \cdot 0001)$; the disease progression rates analysed similarly per optimised threshold (0.04) were $88 / 587$ vs $183 / 425(15 \cdot 0 \%$ [14.7-15.3] vs 43.1\% [42.4-43.7]; $\mathrm{p}<0.0001)$. The optimised 0.47 threshold for mortality resulted in $74 \cdot 8 \%$ sensitivity, $74 \cdot 4 \%$ specificity and $74 \cdot 4 \%$ accuracy; for worsening WHO score, the optimised $0 \cdot 04$ threshold generated $67 \cdot 5 \%$ sensitivity, $67 \cdot 3 \%$ specificity, $67 \cdot 4 \%$ accuracy (table 3). For both endpoints, these estimates were consistent in the early and continued recruitment phases (table 3).

The odds ratios and discriminatory performance of single baseline risk factors are summarised by recruitment phase in appendix $1 \mathrm{p} 12$. In the whole study population, on top of sex, age, body mass index, comorbidities, and the baseline WHO score, COV50 analysed as continuously distributed variable and per threshold significantly improved the AUC (figure 1). For mortality, application of the continuously distributed COV50 marker and the 0.47 COV50 threshold, resulted in an increase of the AUC from 0.835 to $0.854(p=0.0221)$ and from 0.835 to $0.853(p=0.0331)$; for worsening WHO score, the AUC increased from 0.697 to $0.740(p=0.0001)$ for the continuously distributed marker and from 0.697 to 0.730 $(p=0.0008)$ for the 0.04 threshold.

Of 1012 patients, $196(19 \cdot 4 \%)$ received only ambulatory care, of whom 194 (99.0\%) had a baseline COV50 below 0.04 ; the remaining $816(80 \cdot 6 \%)$ patients were hospitalised and carried forward in the computation of predicted hospitalisation costs, based on the Markovchain transition probabilities (appendix $1 \mathrm{p} 13$ ) and the simulated number of patients reaching follow-up WHO scores ranging from 3 to 8 (appendix $1 \mathrm{p} 14$ ). In low-risk patients 
medRxiv preprint doi: https://doi.org/10.1101/2022.01.20.22269599; this version posted January 23,2022 . The copyright holder for this preprint (which was not certified by peer review) is the author/funder, who has granted medRxiv a license to display the preprint in It is made available under a CC-BY-NC-ND 4.0 International license

COV50 as guide to earlier COVID-19 treatment -13-

(COV50 <0.04), the predicted hospitalisation costs standardised to 1000 patients in regular plus intermediate care compared with intensive care were greater (table 4 and appendix $1 \mathrm{p}$ 15): M€ 6.693 (95\% percentile interval, 5.959-7.464) vs M€ 5.427 (4.393-6.589). Among high-risk patients (COV50 $\geq 0 \cdot 04$ ), the hospitalisation costs showed an opposite structure with lower costs in regular plus intermediate vs intensive care: M€ 18.508 (16.952-19.990) vs M€ 23.627 (22.196-25.060), in particular in older ( $\geq 65$ years) high-risk patients

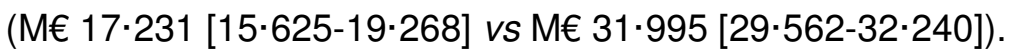

Measures of treatment efficacy, extracted from the literature review (appendix 2) and exemplary trials (appendix $1 \mathrm{p} \mathrm{16}$ ), showed reductions in the number of hospitalisation days or fewer hospitalisation days until recovery. The cost reductions associated with one day less hospitalisation per 1000 patients (table 4) ranged from M€ 1.208 (95\% percentile interval, $1 \cdot 035-1 \cdot 406)$ in the lowest risk category $(\operatorname{COV} 50<0 \cdot 04)$ to M€ $4.503(4 \cdot 107-4 \cdot 864)$ in the highest risk stratum (COV50 $\geq 0.04$ and age $\geq 65$ years).

\section{Discussion}

COV50 is a novel urinary biomarker, consisting of 50 deregulated urinary peptides (appendix $1 \mathrm{pp} 8-10$ ). COV50 predicts death and disease progression over and beyond clinical risk factors, comorbidities and the WHO score at presentation. COV50 analysed as single continuously distributed risk factor generated AUCs for mortality and disease progression substantially greater than a 10-year age increment or 1-point increase in the baseline WHO score (appendix 1 p 12). The optimised COV50 thresholds had $74 \cdot 4 \%$ predictive accuracy for mortality and $67 \cdot 4 \%$ for disease progression (table 3 ). Both COV50 thresholds and COV50 as continuously distributed variable significantly improved the AUC (figure 1). 
medRxiv preprint doi: https://doi.org/10.1101/2022.01.20.22269599; this version posted January 23,2022 . The copyright holder for this preprint (which was not certified by peer review) is the author/funder, who has granted medRxiv a license to display the preprint in It is made available under a CC-BY-NC-ND 4.0 International license .

COV50 as guide to earlier COVID-19 treatment -14-

COV50 is easily administrable, non-invasive, relatively inexpensive balanced against hospitalisation costs, and has high positive and low negative likelihood ratios (table 3). COV50 is registered in Germany and available for clinical and research purposes throughout the European Union. The UPP does not change when urine is stored for 5 days at room temperature in borated test tubes, ${ }^{9}$ thereby providing a wide time window for sample handling, thereby enabling remote testing in non-hospitalised patients with PCR-confirmed COVID-19 infection. UPP profiling requires one day from receipt at the laboratory facility, currently in Hannover, Germany. 9 Furthermore, for research purposes urine can be indefinitely stored at $-20{ }^{\circ} \mathrm{C}$ without UPP alteration. 9 The COV50 test is predictive at the initial stage of infection, when progression to critical illness is still uncertain. Thus, a highrisk test outcome can move patients across the action threshold, allowing the early administration of effective treatments, either in ambulatory or hospitalised care. An extensive literature review (appendix 2) identified effective treatment modalities that might be administered earlier in response to a high-risk UPP risk profile. Such treatments include systemic 10 or inhaled 11 corticosteroids, antiviral agents administered as single agents 12 or cocktails, 13 monoclonal antibodies antagonising the interleukin-6-receptor 14,15 or directed against the viral spike protein, 16,17 or a selective $\sigma 1$-receptor agonist. 18 A few exemplary trials were summarised in appendix 1 ( $p$ 16).

More than 20,000 peptides detectable in a single urine sample provide a bodywide molecular signature of progressing COVID-19 infection generally independent of the virus strain. A prominent characteristic of the COV50 UPP (appendix $1 \mathrm{pp} 8-10$ ) is the shift in collagen fragments, in particular collagen alpha 1(2). Upon infection, the reactive inflammatory cascade activates fibroblasts, 19 leading to excessive extracellular matrix deposition in response to injury. 20 The COV50 UPP signature also points to enhanced $\alpha 1$-antitrypsin degradation in line with reports showing that $\alpha 1$-antitrypsin deficiency is 
medRxiv preprint doi: https://doi.org/10.1101/2022.01.20.22269599; this version posted January 23,2022 . The copyright holder for this preprint (which was not certified by peer review) is the author/funder, who has granted medRxiv a license to display the preprint in It is made available under a CC-BY-NC-ND 4.0 International license .

COV50 as guide to earlier COVID-19 treatment -15-

associated with life-threatening COVID-19.21 Another hallmark of the COV50 UPP is the reduction in urinary peptides derived from CD99.22 This observation reflects the loss of endothelial integrity, interference with transendothelial migration of monocytes, neutrophils and T-cells, 22 and damage of the endothelial tight junctions. The resulting exposure of collagen to the circulating blood triggers the thrombotic complications specific for COVID-19.23 As also observed in chronic obstructive lung disease, 24 with increasing COVID-19 severity, the UPP reveals downregulation of the polymeric immunoglobulin receptor,22 which is highly expressed in trachea and the lung and mediates $\lg \mathrm{A}$ transcytosis. 24

Cost-effectiveness balances health care costs against non-monetary units, such as quality-adjusted life-years (QALYs).25 The QALY-based value proposition is well established in the UK, Sweden, the Benelux and some eastern European countries, but healthcare payers in Germany and France prefer assessing changes in clinical outcomes instead.26 CRIT-Cov-U was not designed to address health-economic issues. The administration of quality-of-life questionnaires, the instruments to turn QALY's into metrics, was impossible in an emergency care setting. Ethics approvals allowing access to claims databases were unavailable. A commonly used definition of the value of human life cannot be applied above age 70 and therefore not to COVID-19-related mortality, given the age distribution of patients. 27 None of the 52 reviewed trials in COVID-19 patients (appendix 2) included a health-economic analysis. However, the simulations in the current article (table 4) provide some information on the balance between the costs of administering the COV50 test (€850 per test; M€ 0.850 per 1000 patients) against potential health care savings associated with earlier intervention, for instance by the reduction in hospitalisation days, reported to be five up to 10 days in three trials. $13,15,28$ As a high UPP risk profile justifies earlier intertervention 
medRxiv preprint doi: https://doi.org/10.1101/2022.01.20.22269599; this version posted January 23,2022 . The copyright holder for this preprint (which was not certified by peer review) is the author/funder, who has granted medRxiv a license to display the preprint in It is made available under a CC-BY-NC-ND 4.0 International license .

COV50 as guide to earlier COVID-19 treatment -16-

over later treatment guided by clinical deterioration, presumably applying the test will not impact on drug costs.

Although COVID-19 affects the heart and kidney, COV50 shares only one urinary peptide with HF1, 13 with CKD273 and two with both classifiers (appendix 1 p 21), which are disease-specific classifiers respectively predictive of left ventricle dysfunction 29 or chronic kidney disease or diabetic nephropathy. 30 Thus, COV50 is highly specific for the molecular pathogenic mechanisms associated with SARS-CoV-2 infection. In addition, the high consistency in the discriminatory performance of COV50 among patients recruited initially and later (tables 2 and 3 ) represents a replication within the CRIT-Cov-U cohort. Nevertheless, the current results must be interpreted within the context of obvious limitations. First, CRIT-CoV-U is an observational cohort study. Randomised clinical trials should consolidate the optimal strategy for applying treatments guided by COV50 risk profiling. Second, as outlined above, future research should address the health-economic implications of the timing and choice of therapeutic interventions in patients with a low $v s$ high risk COV50 score. Third, CRIT-Cov-U enrolled adults and predominantly white Europeans. How ethnicity might affect the UPP is currently under investigation in the Urinary Proteomics Combined with Home Blood Pressure Telemonitoring for Health Care Reform trial (NCT04299529).31 Finally, although UPP risk profiling provides insights on the ideal timing of intervention, vaccination remains by far the primordial strategy in addressing the COVID-19 pandemic, although vaccination alone connot be sufficient to restore the preCOVID-19 way of living. 32

In conclusion, COV50 is the first biomarker predictive of death and disease progression in adult COVID-19 patients. Independent of clinical risk markers, the operational COV50 thresholds have a discriminatory accuracy or around $70 \%$, even in patients with mild disease. A high-risk COV50 test administered within 4 days of a positive PCR-test justifies 
medRxiv preprint doi: https://doi.org/10.1101/2022.01.20.22269599; this version posted January 23,2022 . The copyright holder for this preprint (which was not certified by peer review) is the author/funder, who has granted medRxiv a license to display the preprint in It is made available under a CC-BY-NC-ND 4.0 International license

COV50 as guide to earlier COVID-19 treatment -17-

earlier treatment in patients with mild-to-moderate disease (WHO scores 1-5), in whom clinical risk factors often leave the prognosis uncertain. Another potential application of COV50 is the selection of patients to be enrolled in randomised clinical trials of novel COVID-19 therapies, in which risk is an issue in the choice between ambulatory vs hospitalised care or in the treatment modality to be tested.

\section{Contributors}

RW, HM, JM and JB conceptualised the study. HM, JS, JR and JM did the proteomic urine analyses. JAS and LT did the statistical analysis. JAS reviewed the literature and drafted the research-in-context section. JAS, HM and JB wrote the first draft of the manuscript. YLY did the graphics. All authors contributed to the recruitment and follow-up of patients and to the construction and maintenance of the database, and interpreted the results, commented on successive drafts of the manuscript, and approved the final version.

\section{Data sharing}

The study protocol is available at the German Register for Clinical Studies (www.drks.de), number DRKS00022495. Anonymised participants data will be made available upon request directed to the corresponding author. Proposals will be reviewed and approved by the funder, investigators and collaborators based on scientific merit. After approval of a proposal, data can be shared through a secure online platform after signing a data access and confidentiality agreement. Data will be made available for a minimum of 3 years after a request has been received and approved.

\section{Conflict of interest}

$\mathrm{HM}$ is the co-founder and co-owner of Mosaiques-Diagnostics GmbH, JS and JR are employees of Mosaiques-Diagnostics GmbH, Hannover, Germany. 
medRxiv preprint doi: https://doi.org/10.1101/2022.01.20.22269599; this version posted January 23,2022 . The copyright holder for this preprint (which was not certified by peer review) is the author/funder, who has granted medRxiv a license to display the preprint in It is made available under a CC-BY-NC-ND 4.0 International license

COV50 as guide to earlier COVID-19 treatment -18-

\section{Panel: Research in context}

\section{Evidence before this study}

The literature and guidelines were reviewed with as objective to assess the efficacy of interventions in COVID-19 patients relative to the disease stage at presentation. The PubMed search terms ((COVID-19 OR SARS-CoV-2) AND (clinical trials OR randomised trials OR randomized trials OR RCTs)) identified 52 articles published in English in 2020 and 2021, which were all read and summarised (appendix 2). Eleven studies enrolled ambulatory patients with mild-to-moderate disease, whereas all other recruited hospitalised patients with moderate-to-severe disease. The median number of days from symptom-onset to intervention varied from 1 to 13 days. Corticosteroids, antiviral drugs, anti-inflammatory and antiviral monoclonal antibodies and fluvoxamine reduced the viral load and disease progression, whereas all other tested drugs and convalescent plasma did not modify the disease course. All studies applied clinical criteria, risk factors, comorbidities or diseaseseverity scales to stratify for risk. No study implemented a predictive biomarker to triage patients for ambulatory vs hospital care or to assess the need of early intervention. Among the directives for the management of COVID-19 patients, only the German guideline mentioned the use of COV50, a urinary proteomic profile biomarker.

\section{Added value of this study}

This study is the first to include a COVID-19-specific biomarker to guide early intervention. COV50 consists of 50 differentially regulated urinary peptides and predicts death and disease progression in adults with mild-to-moderate PCR-confirmed COVID-19 infection (WHO scores 1-5). The predictive accuracy of the optimised COV50 thresholds was $74 \cdot 4 \%$ for mortality and $67 \cdot 4 \%$ for disease progression. On top of covariables and the baseline 
medRxiv preprint doi: https://doi.org/10.1101/2022.01.20.22269599; this version posted January 23,2022 . The copyright holder for this preprint (which was not certified by peer review) is the author/funder, who has granted medRxiv a license to display the preprint in It is made available under a CC-BY-NC-ND 4.0 International license

COV50 as guide to earlier COVID-19 treatment $\mathbf{- 1 9}$ -

WHO score, the continuously distributed urinary marker and its optimised thresholds improved the AUCs from 0.835 to 0.854 and to 0.853 for death and from 0.697 to 0.740 and to 0.730 for disease progression, respectively. Using the 0.04 threshold to differentiate low from high COVID-19-associated risk would allow selecting patients with mild disease at presentation for earlier drug treatment, thereby decreasing the risk of worsening disease and death and reducing hospitalisation costs.

\section{Implications of all the available evidence}

The critical question emerging from the 2-year COVID-19 pandemic and most recently from the Omicron variant becoming dominant with high transmissibility is how to prevent deterioration to critical illness in infected patients. A COV50 level of 0.04 or higher predicts disease progression on top of clinical criteria. Even in patients with mild-to-moderate disease (WHO stages 1-5), a high-risk COV50 level is an indication for early in-hospital treatment, thereby valorising the results of the 2020-2021 trials and reducing the burden on health care. COV50 testing can also be applied for the selection of patients in randomised clinical trials of innovative COVID-19 treatment modalities, in which risk at presentation is an issue in the choice between ambulatory vs hospitalised care or in the treatment modality to be tested. COV50 is licensed in Germany and available for clinical use in the European Union. 
medRxiv preprint doi: https://doi.org/10.1101/2022.01.20.22269599; this version posted January 23,2022 . The copyright holder for this preprint (which was not certified by peer review) is the author/funder, who has granted medRxiv a license to display the preprint in It is made available under a CC-BY-NC-ND 4.0 International license .

COV50 as guide to earlier COVID-19 treatment $\mathbf{- 2 0}$ -

\section{References}

1 World Health Organization. Weekly epidemiological update on COVID-19 - 23 November 2021 (https://www.who.int/publications/m/item/weekly-epidemiological-update-on-covid19---23-november-2021; accessed 15 December 2021).

2 Callaway E. Heavily mutated omicron variant puts scientists on alert. Nature 2021; 600: 21.

3 Poudel S, Ishak A, Perez-Fernandez J, et al. Highly mutated SARS-CoV-2 Omicron variant sparks significant concern among global experts - What is known so far? Travel Med Infect Dis 2022; 45: 102234.

4 Wendt R, Thijs L, Kalbitz S, et al. A specific urinary peptidomic profile predicts outcome in SARS-CoV-2-infected patients. eClinicalMedicine 2021; 35: 100883.

5 World Health Organization. Ordinal scale for clinical improvement. WHO R\&D Blueprint Novel Coronavirus, 2021 (https://www.who.int/publications/m/item/a-coordinated-globalresearch-roadmap; accessed 27 December 2021).

6 Wendt R, Kalbitz S, Lübbert C, et al. Urinary proteomics associate with COVID-19 severity: pilot proof-of-principle data and design of multicentric diagnostic study. Proteomics 2020; 20: e2000202.

7 McKinney G, Group G. Markov chains as a predictive analytics technique using SAS/IML, 2018 (https://www.lexjansen.com/wuss/2018/128 Final Paper PDF.pdf; accessed 7 November 2021). 
medRxiv preprint doi: https://doi.org/10.1101/2022.01.20.22269599; this version posted January 23,2022 . The copyright holder for this preprint (which was not certified by peer review) is the author/funder, who has granted medRxiv a license to display the preprint in It is made available under a CC-BY-NC-ND 4.0 International license

COV50 as guide to earlier COVID-19 treatment $-\mathbf{2 1 -}$

8 OECD. Gross domestic product, 2021 (https://doi.org/10.1787/dc2f7aec-en; accessed 14 November 2021).

9 Mischak H, Vlahou A, loannidis JPA. Technical aspects and inter-laboratory variability in native peptide profiling: the CE-MS experience. Clin Biochem 2013; 46: 432-43.

10 The RECOVERY Collaborative Group. Dexamethasone in hospitalized patients with Covid-19. N Engl J Med 2020; 384: 693-704.

11 Yu LM, Bafadhel M, Dorward J, et al. Inhaled budesonide for COVID-19 in people at high risk of complications in the community in the UK (PRINCIPLE): a randomised, controlled, open-label, adaptive platform trial. Lancet 2021; 398: 843-55.

12 Fischer W, Eron JJ, Holman W, et al. Molnupiravir, an oral antiviral treatment for COVID19. medRxiv 2021; https://doi.org/10.1101/2021.06.17.21258639.

13 Hung IFN, Lung KC, Tso EYK, et al. Triple combination of interferon beta-1b, lopinavirritonavir, and ribavirin in the treatment of patients admitted to hospital with COVID-19: an open-label, randomised, phase 2 trial. Lancet 2020; 395: 1695-704.

14 RECOVERY Collaborative Group. Tocilizumab in patients admitted to hospital with COVID-19 (RECOVERY): a randomised, controlled, open-label, platform trial. Lancet 2021; 397: 1637-45.

15 The REMAP-CAP Investigators. Interleukin-6 receptor antagonists in critically ill patients with Covid-19 N Engl J Med 2021; 384: 1491-502.

16 Weinreich DM, Sivapalasingam S, Norton T, et al. REGN-COV2, a neutralizing antibody cocktail, in outpatients with Covid-19. N Engl J Med 2020; 384: 238-51. 
medRxiv preprint doi: https://doi.org/10.1101/2022.01.20.22269599; this version posted January 23,2022 . The copyright holder for this preprint (which was not certified by peer review) is the author/funder, who has granted medRxiv a license to display the preprint in It is made available under a CC-BY-NC-ND 4.0 International license

COV50 as guide to earlier COVID-19 treatment $-\mathbf{2 2 -}$

17 Kim C, Ryu DK, Lee J, et al. A therapeutic neutralizing antibody targeting receptor binding domain of SARS-CoV-2 spike protein. Nat Commun 2021; 12: 288.

18 Reis G, dos Santos Moreira-Silva EA, Silva DCM, et al. Effect of early treatment with fluvoxamine on risk of emergency care and hospitalisation among patients with COVID19: the TOGETHER randomised, platform clinical trial. Lancet Glob Health 2021; 9: doi: 10.1016/S2214-109X(21)00448-4.

19 Bollong MJ, Yang B, Vergani N, et al. Small molecule-mediated inhibition of myofibroblast transdifferentiation for the treatment of fibrosis. Proc Natl Acad Sci 2017; 114: $4679-84$.

20 Trenson S, Hermans H, Craps S, et al. Cardiac microvascular endothelial cells in pressure overload-induced heart disease. Circ Heart Fail 2021; 14: e006979.

21 ERA-EDTA Council and the ERACODA Working Group. Chronic kidney disease is a risk factor for severe COVID-19: a call to action by ERA-EDTA. Nephrol Dial Transplant 2021; 36: gfaa314.

22 Siwy J, Wendt R, Albalat A, et al. CD99 and polymeric immunoglobulin receptor peptides deregulation in critical COVID-19: a potential link to molecular pathophysiology? Proteomics 2021; 21: doi: 10.1002/pmic.202100133.

23 Lopes RD, de Barros e Silva PGM, Furtado RHM, et al. Therapeutic versus prophylactic anticoagulation for patients admitted to hospital with COVID-19 and elevated D-dimer concentration (ACTION): an open-label, multicentre, randomised, controlled trial Lancet 2021; 397: 2253-63. 
medRxiv preprint doi: https://doi.org/10.1101/2022.01.20.22269599; this version posted January 23,2022 . The copyright holder for this preprint (which was not certified by peer review) is the author/funder, who has granted medRxiv a license to display the preprint in It is made available under a CC-BY-NC-ND 4.0 International license

COV50 as guide to earlier COVID-19 treatment -23-

24 Gohy ST, Detry BR, Lecocq M, et al. Polymeric immunoglobulin receptor downregulation in chronic obstructive pulmonary disease. Persistence in the cultured epithelium and role of transforming growth factor- $\beta$. Am J Respir Crit Care Med 2014; 190: 509-21.

25 Kimhofer T, Lodge S, Whiley L, et al. Integrative modeling of quantitative plasma lipoprotein, metabolic, and amino acid data reveals a multiorgan pathological signature of SARS-CoV=2 infection. J Proteome Res 2020; 19: 4442-54.

26 Johannesson $M$. The relationship between cost-effectiveness analysis and cost-benefit analysis. Soc Sci Med 1995; 41: 483-89.

27 Staessen JA, Thijs L, Yang WY et al. Interpretation of population health metrics. Environmental lead exposure as exemplary case. Hypertension 2020; 74: 603-14.

28 Beigel JH, Tomashek KM, Dodd LE, et al. Remdesivir for the treatment of Covid-19 Final Report N Engl J Med 2020; 383: 1813-26.

29 Zhang ZY, Nkuipou-Kenfack E, Staessen JA. Urinary peptidomic biomarker for personalized prevention and treatment of diastolic left ventricular dysfunction. Proteomics Clin Appl 2019; 13: e1800174.

30 Tofte N, Lindhardt M, Adamova K, et al. Early detection of diabetic kidney disease by urinary proteomics and subsequent intervention with spironolactone to delay progression (PRIORITY) : a prospective observational study and embedded randomised placebocontrolled trial. Lancet Diabetes Endocrinol 2020; 8: 301-12. 
medRxiv preprint doi: https://doi.org/10.1101/2022.01.20.22269599; this version posted January 23, 2022. The copyright holder for this preprint (which was not certified by peer review) is the author/funder, who has granted medRxiv a license to display the preprint in It is made available under a CC-BY-NC-ND 4.0 International license.

COV50 as guide to earlier COVID-19 treatment -24-

31 Thijs L, Asayama K, Maestre GE, et al. Urinary proteomics combined with home blood pressure telemonitoring for health care reform trial: rational and protocol. Blood Press 2021; 30: 269-81.

32 Peiris M, Leung GM. What can we expect from first-generation COVID-19 vaccines? Lancet 2020; 396: 1467-69. 
medRxiv preprint doi: https://doi.org/10.1101/2022.01.20.22269599; this version posted January 23, 2022. The copyright holder for this preprint (which was not certified by peer review) is the author/funder, who has granted medRxiv a license to display the preprint in It is made available under a CC-BY-NC-ND 4.0 International license

COV50 as guide to earlier COVID-19 treatment -25-

\section{Legend to figure 1}

Figure 1: Performance of the COV50 urinary marker on top of other baseline risk factors in the full dataset for contrasting mortality vs survival (panels A-C) and for progression vs non-progression in the baseline WHO score during follow-up (panels

D-F). The base model included sex, age, body mass index and the presence of comorbidities: hypertension, heart failure, diabetes or cancer. In subsequent steps, the baseline WHO score was added and next COV50 as a continuously distributed variable (panels $B$ and $E$ ) or as a categorised variable based on an optimised threshold of 0.47 for mortality (panel C) or 0.04 for a worsening WHO score (panel F). 
Table 1: Baseline characteristics

\begin{tabular}{|c|c|c|c|c|}
\hline \multirow{2}{*}{ Characteristic } & \multicolumn{3}{|c|}{ Recruitment phase } & \multirow{2}{*}{$\begin{array}{l}\text { Full } \\
\text { study }\end{array}$} \\
\hline & Initial & Continued & $p$ value & \\
\hline Number in cohort & 228 & 784 & & 1012 \\
\hline \multicolumn{5}{|l|}{ Main study variables } \\
\hline \multicolumn{5}{|l|}{ WHO score } \\
\hline $1-3$ & $90(39 \cdot 5)$ & $355(45 \cdot 3)$ & & $445(44 \cdot 0)$ \\
\hline $4-5$ & $107(46 \cdot 9)$ & $422(53 \cdot 8)$ & $<0.0001$ & $529(52 \cdot 3)$ \\
\hline 6 & $31(13 \cdot 6)$ & $7(0.9)$ & & $38(3 \cdot 8)$ \\
\hline COV50 level & $-0 \cdot 19(1 \cdot 52)$ & $-0 \cdot 24(1 \cdot 36)$ & 0.5918 & $-0.23(1 \cdot 40)$ \\
\hline \multicolumn{5}{|l|}{ Number with characteristic (\%) } \\
\hline White ethnicity & $205(89 \cdot 9)$ & $685(87 \cdot 4)$ & 0.2999 & $890(87 \cdot 9)$ \\
\hline Women & $94(41 \cdot 2)$ & $353(45 \cdot 0)$ & 0.3095 & $447(44 \cdot 2)$ \\
\hline Hypertension & $137(60 \cdot 1)$ & $420(53 \cdot 6)$ & 0.0817 & $557(55 \cdot 0)$ \\
\hline Heart failure & $30(13 \cdot 6)$ & $124(15 \cdot 8)$ & 0.3253 & $154(15 \cdot 2)$ \\
\hline Body mass index $\geq 30 \mathrm{~kg} / \mathrm{m}^{2}$ & $59(29 \cdot 8)$ & $192(24 \cdot 5)$ & 0.6694 & $251(24 \cdot 8)$ \\
\hline Diabetes mellitus & $65(28 \cdot 5)$ & $192(24 \cdot 5)$ & 0.2198 & $257(25 \cdot 4)$ \\
\hline Cancer & $13(5 \cdot 7)$ & $93(11 \cdot 9)$ & 0.0117 & $106(10 \cdot 5)$ \\
\hline Use of RAS blockers, & $122(53 \cdot 5)$ & $305(38.9)$ & $<0.0001$ & $427(42 \cdot 2)$ \\
\hline \multicolumn{5}{|l|}{ Mean (SD) of characteristic } \\
\hline Age & $63 \cdot 1(17 \cdot 1)$ & $62 \cdot 1(18 \cdot 0)$ & 0.4556 & $62 \cdot 3(17 \cdot 8)$ \\
\hline Systolic blood pressure, $\mathrm{mm} \mathrm{Hg}$ & $129 \cdot 8(23 \cdot 2)$ & $127 \cdot 7(19 \cdot 0)$ & $0 \cdot 1633$ & $128 \cdot 2(20 \cdot 1)$ \\
\hline Diastolic blood pressure, $\mathrm{mm} \mathrm{Hg}$ & $75.9(13.5)$ & $76 \cdot 2(11 \cdot 7)$ & 0.7436 & $76 \cdot 2(12 \cdot 2)$ \\
\hline Heart rate, beats per minute & $83 \cdot 4(15 \cdot 1)$ & $81 \cdot 9(15 \cdot 6)$ & 0.2074 & $82 \cdot 2(15 \cdot 5)$ \\
\hline Body mass index, $\mathrm{kg} / \mathrm{m}^{2}$ & $28 \cdot 0(5 \cdot 4)$ & $27 \cdot 5(5 \cdot 2)$ & 0.2252 & $27 \cdot 6(5 \cdot 2)$ \\
\hline
\end{tabular}

RAS blockers indicate blocker of the renin-angiotensin system, including angiotensin-converting enzyme inhibitors and angiotensin-receptor blockers. Systolic and diastolic blood pressure and heart rate were missing in 2 initially recruited participants and 29 participants recruited later. The $p$ value refers to the differences in the study participants' characteristics between initial recruitment (25 March 2020 - 18 November 2020$)$ and continued recruitment (30 April 2020 - 14 April 2021). RAS=renin-angiotensin system. 
Table 2: Odds ratios relating outcome to COV50 by recruitment phase

\begin{tabular}{|c|c|c|c|c|c|c|}
\hline \multirow{2}{*}{ Outcome } & \multicolumn{2}{|c|}{ Initial } & \multicolumn{2}{|c|}{ Continued } & \multicolumn{2}{|l|}{ Full } \\
\hline & OR $(95 \% \mathrm{Cl})$ & $p$ value & OR $(95 \% \mathrm{Cl})$ & p value & OR $(95 \% \mathrm{Cl})$ & $p$ value \\
\hline \multicolumn{7}{|l|}{ Mortality } \\
\hline $\mathrm{N}^{\circ}$ deaths/at risk (\%) & $25 / 228(11 \cdot 0)$ & & $94 / 784(12 \cdot 0)$ & & $119 / 1012(11 \cdot 8)$ & \\
\hline Unadjusted & $2 \cdot 45(1.69-3.54)$ & $<0.0001$ & $2 \cdot 47(2 \cdot 02-3 \cdot 03)$ & $<0.0001$ & $2 \cdot 44(2 \cdot 05-2 \cdot 92)$ & $<0.0001$ \\
\hline \multicolumn{7}{|l|}{ Adjusted } \\
\hline Sex and age & $2 \cdot 30(1 \cdot 57-3 \cdot 37)$ & $<0.0001$ & $1 \cdot 88(1 \cdot 50-2 \cdot 35)$ & $<0.0001$ & $2 \cdot 04(1 \cdot 68-2 \cdot 47)$ & $<0.0001$ \\
\hline + baseline WHO score & $2 \cdot 18(1 \cdot 30-3 \cdot 64)$ & 0.0030 & $1 \cdot 54(1 \cdot 21-1 \cdot 96)$ & 0.0005 & $1 \cdot 65(1 \cdot 34-2 \cdot 05)$ & $<0.0001$ \\
\hline$+\mathrm{BMI}$ and comorbidities & $2 \cdot 27(1 \cdot 34-3 \cdot 83)$ & 0.0023 & $1 \cdot 55(1 \cdot 21-1 \cdot 98)$ & 0.0005 & $1 \cdot 67(1 \cdot 34-2 \cdot 07)$ & $<0.0001$ \\
\hline \multicolumn{7}{|l|}{ Progressing WHO score } \\
\hline $\mathrm{N}^{\circ}$ events/at risk (\%) & $50 / 228(21 \cdot 9)$ & & $221 / 784(28 \cdot 3)$ & & $271 / 1012(26 \cdot 8)$ & \\
\hline Unadjusted & $1.95(1 \cdot 52-2 \cdot 51)$ & $<0.0001$ & $1 \cdot 77(1 \cdot 56-2 \cdot 02)$ & $<0.0001$ & $1 \cdot 79(1 \cdot 60-2 \cdot 01)$ & $<0.0001$ \\
\hline \multicolumn{7}{|l|}{ Adjusted } \\
\hline Sex and age & $1 \cdot 81(1 \cdot 38-2 \cdot 35)$ & $<0.0001$ & $1 \cdot 50(1 \cdot 29-1 \cdot 73)$ & $<0.0001$ & $1 \cdot 56(1 \cdot 38-1 \cdot 77)$ & $<0.0001$ \\
\hline + baseline WHO score & $2 \cdot 32(1 \cdot 56-3 \cdot 46)$ & $<0.0001$ & $1.52(1 \cdot 29-1 \cdot 79)$ & $<0.0001$ & $1 \cdot 65(1 \cdot 42-1 \cdot 92)$ & $<0.0001$ \\
\hline + BMI and comorbidities & $2 \cdot 32(1 \cdot 55-3 \cdot 48)$ & $<0.0001$ & $1 \cdot 51(1 \cdot 27-1 \cdot 78)$ & $<0.0001$ & $1 \cdot 63(1 \cdot 40-1 \cdot 90)$ & $<0.0001$ \\
\hline
\end{tabular}

Odds ratios given with $95 \%$ confidence interval express the risk for 1-SD increment in COV50. Initial recruitment lasted from 25 March 2020 until 18 November 2020 and continued recruitment from 30 April 2020 until 14 April 2021. Comorbidities include hypertension, heart failure, diabetes and cancer. $\mathrm{BMl}=$ body mass index. 
Table 3: Discriminative performance of COV50 by recruitment phase

\begin{tabular}{|c|c|c|c|}
\hline Outcome & Initial & Continued & Full \\
\hline \multicolumn{4}{|l|}{ Mortality } \\
\hline $\mathrm{N}^{\circ}$ deaths/at risk (\%) & $25 / 228(11 \cdot 0)$ & $94 / 784(12 \cdot 0)$ & $119 / 1012(11 \cdot 8)$ \\
\hline \multicolumn{4}{|l|}{ Continuously distributed COV50 } \\
\hline AUC (95\% confidence interval) & $0.83(0.77-0.90)$ & $0.83(0.77-0.90)$ & $0.81(0.77-0.85)$ \\
\hline \multicolumn{4}{|l|}{ Categorised COV50 } \\
\hline Youden cut-off threshold & 0.47 & 0.47 & $0 \cdot 47$ \\
\hline Sensitivity ( $95 \%$ confidence interval) & $88 \cdot 0(68 \cdot 8-97 \cdot 4)$ & $71 \cdot 3(61 \cdot 0-80 \cdot 1)$ & $74 \cdot 8(66 \cdot 0-82 \cdot 3)$ \\
\hline Specificity (95\% confidence interval) & $75 \cdot 4(68 \cdot 9-81 \cdot 1)$ & $75 \cdot 5(72 \cdot 2-78 \cdot 6)$ & $74 \cdot 4(71 \cdot 4-77 \cdot 2)$ \\
\hline PLR (95\% confidence interval) & $2 \cdot 57(2 \cdot 70-4 \cdot 73)$ & $2 \cdot 91(2 \cdot 43-3 \cdot 48)$ & $2 \cdot 92(2 \cdot 50-3 \cdot 40)$ \\
\hline NLR (95\% confidence interval) & $0.16(0.05-0.46)$ & $0.38(0.28-0.52)$ & $0.34(0.25-0.46)$ \\
\hline Accuracy & $76 \cdot 8(70 \cdot 7-82 \cdot 1)$ & $75 \cdot 0(71 \cdot 9-77 \cdot 9)$ & $74 \cdot 4(71 \cdot 6-77 \cdot 1)$ \\
\hline \multicolumn{4}{|l|}{ Progressing WHO score } \\
\hline $\mathrm{N}^{\circ}$ events/at risk (\%) & $50 / 228(21 \cdot 9)$ & $221 / 784(28 \cdot 3)$ & $271 / 1012(26 \cdot 8)$ \\
\hline \multicolumn{4}{|l|}{ Continuously distributed COV50 } \\
\hline AUC (95\% confidence interval) & $0.76(0.69-0.83)$ & $0.76(0.69-0.83)$ & $0.72(0.68-0.75)$ \\
\hline \multicolumn{4}{|l|}{ Categorised COV50 } \\
\hline Youden cut-off threshold & $0 \cdot 04$ & $0 \cdot 04$ & $0 \cdot 04$ \\
\hline Sensitivity ( $95 \%$ confidence interval) & $80 \cdot 0(66 \cdot 3-90 \cdot 0)$ & $64 \cdot 7(58 \cdot 0-71 \cdot 0)$ & $67 \cdot 5(61 \cdot 6-73 \cdot 1)$ \\
\hline Specificity (95\% confidence interval) & $64 \cdot 6(57 \cdot 1-71 \cdot 6)$ & $68 \cdot 2(64 \cdot 2-72 \cdot 0)$ & $67 \cdot 3(63 \cdot 8-70 \cdot 7)$ \\
\hline PLR (95\% confidence interval) & $2 \cdot 26(1 \cdot 77-2 \cdot 88)$ & $2 \cdot 04(1 \cdot 74-2 \cdot 38)$ & $2 \cdot 07(1 \cdot 81-2 \cdot 36)$ \\
\hline NLR (95\% confidence interval) & $0 \cdot 31(0 \cdot 18-0 \cdot 54)$ & $0.52(0.43-0.62)$ & $0.48(0.40-0.58)$ \\
\hline Accuracy & $68 \cdot 0(61 \cdot 5-74 \cdot 0)$ & $67 \cdot 2(63 \cdot 8-70 \cdot 5)$ & $67 \cdot 4(64 \cdot 1-70 \cdot 3)$ \\
\hline
\end{tabular}


Table 4: Simulated hospitalisation costs by baseline Cov50 level, the hospital facility at entry, and age class (starts)

\begin{tabular}{|c|c|c|c|c|c|c|}
\hline \multirow{2}{*}{$\begin{array}{l}\text { Baseline Cov50 } \\
\text { Entry hospital facility }\end{array}$} & \multirow{2}{*}{ Item } & \multicolumn{4}{|c|}{$\begin{array}{l}\text { Hospital costs expressed per } 1000 \text { patients based on the number of patients } \\
\text { reaching a follow-up WHO score ranging from } 3 \text { to } 8 \text { in the Markov chain simulation }\end{array}$} & \multirow{2}{*}{$\begin{array}{l}\text { Cost reduction } \\
\text { associated with } 1 \text {-day } \\
\text { less hospitalisation } \\
\text { per } 1000 \text { patients }\end{array}$} \\
\hline & & $3-4$ & 5 & $6-8$ & $3-8$ & \\
\hline \multicolumn{7}{|l|}{$[-3 \cdot 26,3 \cdot 39[$} \\
\hline \multirow[t]{2}{*}{ Regular care } & days & $9(4-45)$ & $10(1-37)$ & $6(1-51)$ & & \\
\hline & $\mathrm{M} €$ & $4 \cdot 304(4 \cdot 103-4 \cdot 504)$ & $0.906(0.805-1.006)$ & $1 \cdot 956(1 \cdot 735-2 \cdot 189)$ & & \\
\hline \multirow[t]{2}{*}{ Intermediate care } & days & & $6(3-23)$ & $11(1-47)$ & & \\
\hline & $M €$ & & $1.736(1.543-1.929)$ & $2 \cdot 986(2 \cdot 649-3 \cdot 342)$ & & \\
\hline \multirow[t]{2}{*}{ Intensive care } & days & & & $6(3-42)$ & & \\
\hline & $M €$ & & & $9 \cdot 048(8 \cdot 025-10 \cdot 125)$ & & \\
\hline \multirow[t]{2}{*}{ All care facilities } & days & & & & $10(1-35)$ & \\
\hline & $\mathrm{M} €$ & & & & $20 \cdot 935(18 \cdot 860-23 \cdot 095)$ & $2 \cdot 094(1 \cdot 866-2 \cdot 309)$ \\
\hline \multicolumn{7}{|l|}{$<0.04$} \\
\hline \multirow[t]{2}{*}{ Regular care } & days & $9(3-21)$ & $8(3-45)$ & $12(1-51)$ & & \\
\hline & $\mathrm{M} €$ & $3 \cdot 121(2 \cdot 946-3 \cdot 297)$ & $0.589(0.514-0.664)$ & $0.880(0.712-1.069)$ & & \\
\hline \multirow[t]{2}{*}{ Intermediate care } & days & & $9(4-19)$ & $18(14-22)$ & & \\
\hline & $M €$ & & $1 \cdot 341(1 \cdot 170-1 \cdot 511)$ & $0.762(0.617-0.926)$ & & \\
\hline \multirow[t]{2}{*}{ Intensive care } & days & & & $4(3-6)$ & & \\
\hline & $M €$ & & & $5 \cdot 427(4 \cdot 393-6 \cdot 589)$ & & \\
\hline \multirow[t]{2}{*}{ All care facilities } & days & & & & $10(3-25)$ & \\
\hline & $\mathrm{M} €$ & & & & $12 \cdot 120(10 \cdot 352-14 \cdot 053)$ & $1 \cdot 212(1 \cdot 035-1 \cdot 405)$ \\
\hline \multicolumn{7}{|l|}{$\geq 0.04,[19,96 y[$} \\
\hline \multirow[t]{2}{*}{ Regular care } & days & $9(3-24)$ & $9(5-59)$ & $5(1-53)$ & & \\
\hline & $\mathrm{M} €$ & $2 \cdot 588(2 \cdot 300-2 \cdot 843)$ & $0.818(0.658-0.961)$ & $5 \cdot 015(4 \cdot 711-5 \cdot 319)$ & & \\
\hline \multirow[t]{2}{*}{ Intermediate care } & days & & $6(3-23)$ & $11(1-47)$ & & \\
\hline & $\mathrm{M} €$ & & $1 \cdot 445(1 \cdot 165-1 \cdot 701)$ & $8 \cdot 642(8 \cdot 118-9 \cdot 166)$ & & \\
\hline \multirow[t]{2}{*}{ Intensive care } & days & & & $6(3-42)$ & & \\
\hline & $M €$ & & & $23 \cdot 627(22 \cdot 196-25 \cdot 060)$ & & \\
\hline \multirow[t]{2}{*}{ All care facilities } & days & & & & $11(3-34)$ & \\
\hline & $M €$ & & & & $42 \cdot 135(39 \cdot 148-45 \cdot 050)$ & $3.830(3.559-4.095)$ \\
\hline
\end{tabular}


Table 4: Simulated hospitalisation costs by baseline cov50 level, hospital facility at presentation, and age class (continued)

\begin{tabular}{|c|c|c|c|c|c|c|c|}
\hline \multirow{2}{*}{$\begin{array}{l}\text { Baseline COV50 } \\
\text { Entry hospital facility }\end{array}$} & \multirow{2}{*}{ Item } & \multicolumn{4}{|c|}{$\begin{array}{l}\text { Hospital costs expressed per } 1000 \text { patients based on the number of patients } \\
\text { reaching a follow-up WHO score ranging from } 3 \text { to } 8 \text { in the Markov chain simulation }\end{array}$} & \multirow{2}{*}{$\begin{array}{l}\text { Cost reduction } \\
\text { associated with 1-day } \\
\text { less hospitalisation } \\
\text { per } 1000 \text { patients }\end{array}$} & \\
\hline & & $3-4$ & 5 & $6-8$ & $3-8$ & & \\
\hline \multicolumn{8}{|l|}{$\geq 0.04,<65 y$} \\
\hline \multirow[t]{2}{*}{ Regular care } & days & $9(2-20)$ & $9(5-76)$ & $9(1-30)$ & & & $\underset{\bar{C}}{\bar{P}}$ \\
\hline & $M €$ & $2 \cdot 310(1 \cdot 897-2 \cdot 666)$ & $1 \cdot 386(1 \cdot 134-1 \cdot 638)$ & $4 \cdot 613(4 \cdot 135-5 \cdot 169)$ & & & $\stackrel{\infty}{3}$ \\
\hline \multirow[t]{2}{*}{ Intermediate care } & days & & $5(3-17)$ & $11(3-25)$ & & & $\stackrel{0}{0}$ \\
\hline & $M €$ & & $2 \cdot 780(2 \cdot 275-3 \cdot 285)$ & $6 \cdot 718(6 \cdot 023-7 \cdot 529)$ & & & $\underset{\infty}{\infty}$ \\
\hline \multirow[t]{2}{*}{ Intensive care } & days & & & $5(3-49)$ & & & $\stackrel{\underline{\overline{0}}}{\overline{0}}$ \\
\hline & $m €$ & & & $27 \cdot 582(24 \cdot 729-30 \cdot 911)$ & & & $\frac{O}{D}$ \\
\hline \multirow[t]{2}{*}{ All care facilities } & days & & & & $12(3-32)$ & & 흥 \\
\hline & $\mathrm{M} €$ & & & & $45 \cdot 389(40 \cdot 193-51 \cdot 198)$ & $3 \cdot 782(3.349-4 \cdot 266)$ & 幽 \\
\hline \multicolumn{7}{|l|}{$\geq 0.04, \geq 65 y$} & 边 \\
\hline \multirow[t]{2}{*}{ Regular care } & days & $9(3-27)$ & $13(5-59)$ & $4(1-53)$ & & & 罗蛋 \\
\hline & $m €$ & $2 \cdot 224(2 \cdot 214-2 \cdot 853)$ & $0.620(0.421-0.768)$ & $5 \cdot 351(4 \cdot 944-5 \cdot 726)$ & & & p. \\
\hline \multirow[t]{2}{*}{ Intermediate care } & days & & $7(2-24)$ & $5(1-47)$ & & & z \\
\hline & $\mathrm{M} €$ & & $1 \cdot 243(0 \cdot 845-1 \cdot 541)$ & $7 \cdot 793(7 \cdot 201-8 \cdot 380)$ & & & $\dot{0}$ \\
\hline \multirow[t]{2}{*}{ Intensive care } & days & & & $12(1-42)$ & & & $\underset{\overrightarrow{\mathbb{D}}}{\overline{\bar{D}}}$ \\
\hline & $\mathrm{M} €$ & & & $31 \cdot 995(29 \cdot 562-34 \cdot 240)$ & & & 荘 \\
\hline \multirow[t]{2}{*}{ All care facilities } & days & & & & $11(2-37)$ & & $\overrightarrow{\overline{0}}$ \\
\hline & $M €$ & & & & $49 \cdot 226(45 \cdot 187-53 \cdot 508)$ & $4 \cdot 503(4 \cdot 107-4 \cdot 864)$ & $\stackrel{\varrho}{\overline{\bar{\alpha}}}$ \\
\hline \multicolumn{8}{|c|}{$\begin{array}{l}\text { Hospital costs per care facility (median and } 95 \% \text { percentile interval) were extrapolated from the distribution of patients to be expected by Markov chain simulation reaching follow-up WHO scores } \\
\text { of } 3-4,5 \text {, and } 6-8 \text { and the care facility corresponding with disease severity, i.e., regular, intermediate and intensive care for scores } 3-4,5 \text {, and } 6-8 \text {, respectively. Given the simulated number of } \\
\text { patients, hospitalisation costs were then computed based on the median number of hospital days per care facility, as observed in the CRIT-Cov-U cohort and a flat facility-specific costing rate } \\
\text { harmonised across countries using the } 2020 \text { national gross domestic product with the costs in Germany as reference. Hospitalisation costs were standardised to } 1000 \text { patients in each risk } \\
\text { stratum. Days refers to the median number of days ( } 95 \% \text { percentile interval) as observed in the CRIT-Cov-U cohort. M€ indicates million Euro. }\end{array}$} \\
\hline
\end{tabular}


medRxiv preprint doi: https://doi.org/10.1101/2022.01.20.22269599; this version posted January $23,2022$. The copyright holder for this preprint (which was not certified by peer review) is the author/funder, who has granted medRxiv a license to display the preprint in It is made available under a CC-BY-NC-ND 4.0 International license

COV50 as guide to earlier COVID-19 treatment -31-

[A]
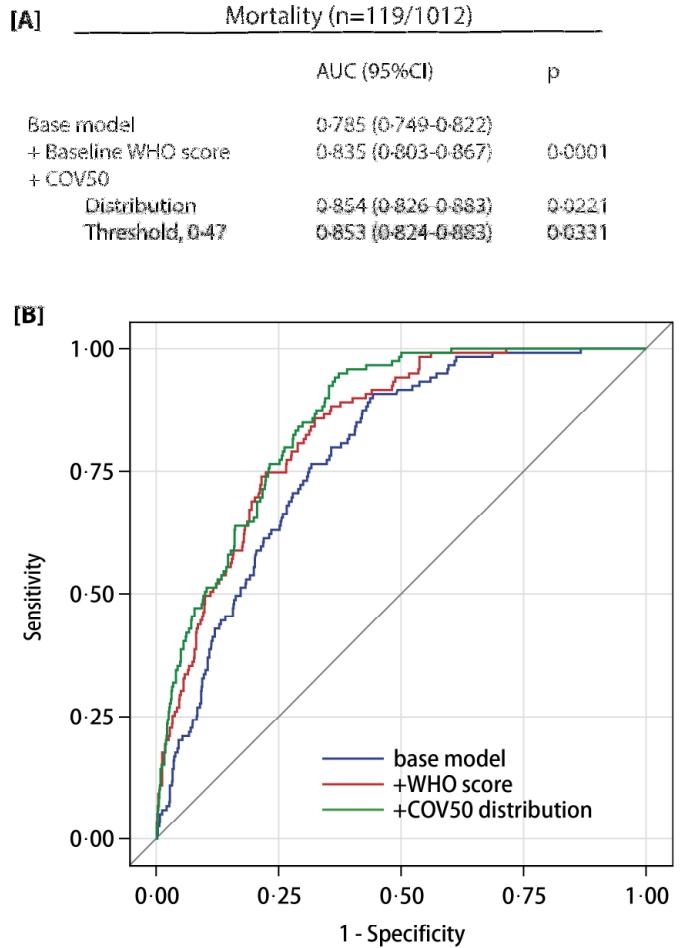

[C]

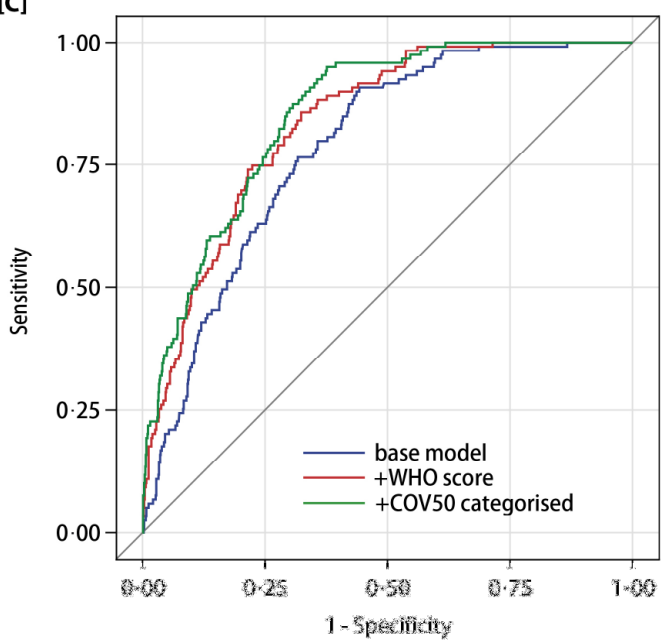

[D] Worsening WHO score $(n=271 / 1012)$

\begin{tabular}{|c|c|}
\hline 3 se model & $0.605(06590730)$ \\
\hline $\begin{array}{l}\text { + Baseline WHO soore } \\
+ \text { Cov50 }\end{array}$ & $0697(0652-0732)$ \\
\hline Discribution. & $0.740,0.707-0.773)$ \\
\hline Threshold 004 & $5730(0-606-0764)$ \\
\hline
\end{tabular}

[E]

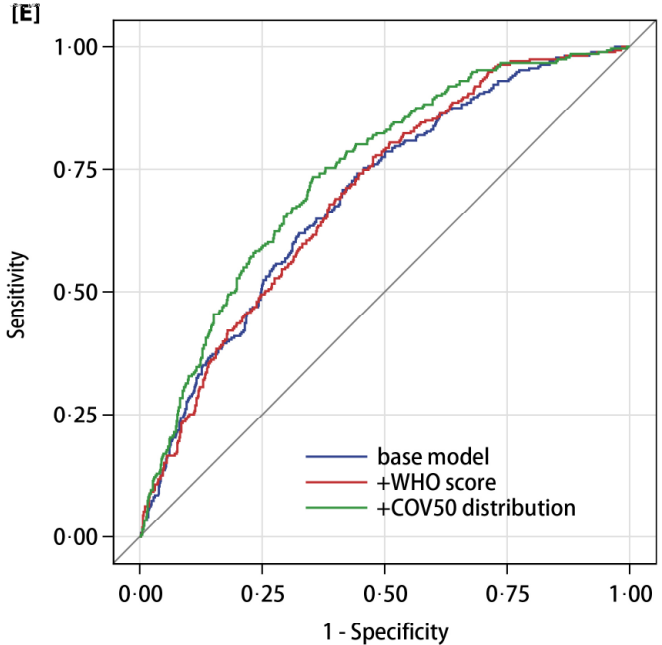

[F]

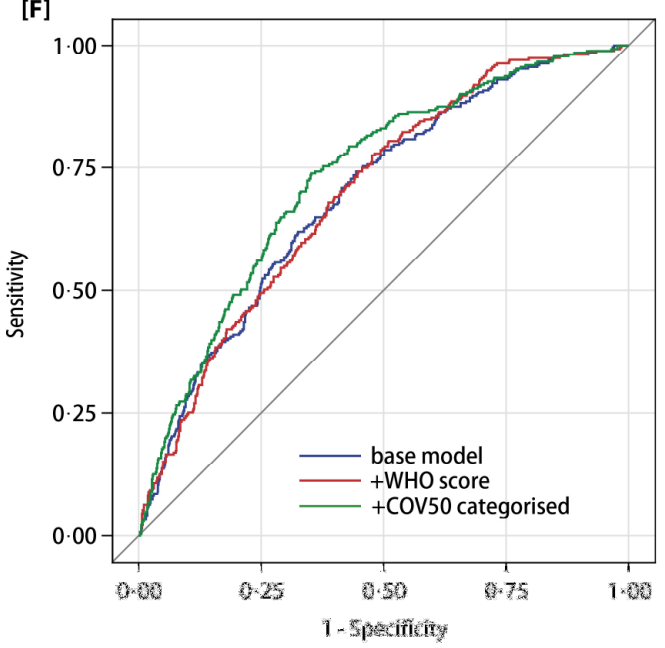

Figure 1:

Performance of the COV50 urinary marker on top of other baseline risk factors in the full dataset for contrasting mortality vs survival (panels A-C) and for progression vs non-progression in the baseline WHO score during follow-up (panels D-F).

The base model included sex, age, body mass index and the presence of comorbidities: hypertension, heart failure, diabetes or cancer. In subsequent steps, the baseline WHO score was added and next COV50 as a continuously distributed variable (panels $B$ and $E$ ) or as a categorised variable based on an optimised threshold of 0.47 for mortality (panel C) or 0.04 for a worsening WHO score (panel F). 